\title{
Organizacija informacija i katalogizacija: temelj obrazovanja informacijskih stručnjaka
}

\section{Information organization and cataloguing: the basis of information professionals education}

\section{Kristina Feldvari ${ }^{1}$, Izabel Zdravčević ${ }^{2}$, Martina Glumac ${ }^{3}$}

APSTRAKT: Podučavanje i učenje učinkovitog organiziranja informacija složeni su procesi i za edukatore i za studente. Katalogizacija, koja je definirana kao postupak organiziranja informacija izradom bibliografskih zapisa, utvrđeni je postupak za postizanje navedenog cilja. Učenje katalogizacije studentima može biti teško jer se moraju upoznati s velikom količinom novih složenih sadržaja, a vještine kvalitetnog katalogiziranja stječu se godinama. Sva potrebna znanja i vještine trebaju se moći uspješno prenijeti studentima kroz kolegije na kojima se podučava organizacija informacija i katalogizacija. Stoga su se edukatori godinama trudili pronaći najbolje načine kako bi proces prenošenja znanja učinili što uspješnijim. $U$ ovome radu je dan prikaz svrhe i načina podučavanja $i$ učenja organizacije informacija, kao i važnosti i mjesta kojeg budući stručnjaci informacijskih znanosti imaju u današnjem online okruženju. $U$ radu je također prikazano izvođenje praktične nastave $i$ podučavanja katalogizacije iz kolegija Organizacija informacija I i Teorija i praksa organizacije informacija na Odsjeku za informacijske znanosti u Osijeku. Odsjek je akademske godine 2019./2020. u dogovoru s Institutom informacijskih znanosti IZUM iz Maribora dobio pristup za rad u njihovom knjižničnom sustavu COBISS. Sustav je kasnije korišten kao jedini sustav za potrebe izvođenja praktične virtualne nastave tijekom pandemije uzrokovane koronavirusom. Dodatni cilj rada je, stoga, bio prezentirati rezultate ankete koja je provedena među studentima preddiplomskog i diplomskog studija Odsjeka u studenom 2020. godine o iskustvima i stavovima o COBISS sustavu te općenito načinu održavanja vježbi iz deskriptivne katalogizacije u virtualnom okruženju.

KLJUČNE RIJEČI: organizacija informacija, katalogizacija, edukacija katalogizatora, virtualna nastava

ABSTRACT: Teaching and learning how to organize information effectively is a complex process both for educators and students. Cataloguing, which is defined as the process of organizing information by making bibliographic records, is the established procedure for achieving the goal mentioned. Learning the process of cataloguing can be difficult for students because they must become familiar with a large amount of new and complex contents. Apart from that, the skill of exceptional cataloguing is being acquired over the years of working in the field. Since according to our syllabi, the sufficient knowledge and skills should be successfully transferred to students through courses that teach information organization and cataloguing, educators have been trying for years to find the best ways to make the process of transferring it to students as successful as possible. The present paper addresses the purpose and the manner of teaching and learning the information organization as well as the importance and place that future information science professionals have in the contemporary online environment. The paper presents the implementation of the practical classes and the teaching of the process of cataloguing through the courses Organizacija informacija (Organisation of Information) and

\footnotetext{
${ }^{1}$ Kontakt autora: doc. dr. sc. Kristina Feldvari, Sveučilište Josipa Jurja Strossmayera u Osijeku, Filozofski fakultet, Odsjek za informacijske znanosti, Osijek, Hrvatska, kfeldvari@ffos.hr.

2 Izabel Zdravčević, studentica, Sveučilište Josipa Jurja Strossmayera u Osijeku, Filozofski fakultet, Odsjek za informacijske znanosti, Osijek, Hrvatska, izdravcevic@ffos.hr.

${ }^{3}$ Martina Glumac, studentica, Sveučilište Josipa Jurja Strossmayera u Osijeku, Filozofski fakultet, Odsjek za informacijske znanosti, Osijek, Hrvatska, mglumac@ffos.hr.
} 
Teorija i praksa organizacije informacija (Theory and Practice of Organisation of Information) at the Department of Information Sciences of the University of Osijek. In agreement with the Institute of Information Sciences IZUM from Maribor, our Department was given access to work in their COBISS library system in the academic year 2019/2020. The system was later used as the only system for the purpose of conducting practical online teaching at the University of Osijek during the COVID-19 pandemic. An additional aim of the paper was therefore to present the results of a survey conducted among undergraduate and graduate students on the experiences and attitudes based on working with COBISS, as well as their opinion on the virtual practical courses on descriptive cataloguing.

KEYWORDS: information organization, cataloguing, education of cataloguers, online teaching

\section{Uvod}

Trinaest godina osobnog iskustva kao edukatora u podučavanju organizacije informacija, razgovora i diskusije sa studentima o načinima izvođenja praktične nastave, kao i brojni pokušaji shvaćanja i iznalaženja najboljih načina podučavanja deskriptivne katalogizacije, bili su jedan od poticaja za pisanje ovog rada. Uz podučavanje svrhe, postupaka i procesa deskriptivne katalogizacije, kao drugi poticaj se svakako može navesti situacija u kojoj su se tijekom 2020. godine našli studenti i profesori većine hrvatskih sveučilišta. Naime, uslijed pandemije izazvane koronavirusom većina nastave na Sveučilištu u Osijeku, a time i na Odsjeku za informacijske znanosti u Osijeku, najvećim je dijelom održavana virtualno. Navedeno je uzrokovalo potrebu za prilagodbom profesora virtualnom okruženju izvođenja nastave, a naročito u smislu prilagođavanja praktične nastave, odnosno vježbi iz katalogizacije, čija kvaliteta izvođenja može biti poprilično narušena u virtualnom okruženju. Katalogizacija je složen proces, zato se vještine potrebne za nju razvijaju godinama. lako katalogizaciju prvenstveno obavljaju katalogizatori, u idealnom slučaju svi informacijski stručnjaci bi trebali razumjeti katalogizaciju kako bi mogli učinkovito pretraživati online katalog knjižnice ili baze podataka te na taj način pomoći korisnicima.

S obzirom na navedeno, cilj ovoga rada je objasniti svrhu učenja učinkovitog organiziranja informacija i katalogizacije te važnost i mjesto koju budući zaposlenici, studenti informacijskih znanosti, imaju u današnjem online okruženju. U radu je prikazano izvođenje praktične nastave iz kolegija Organizacija informacija I na preddiplomskom studiju te kolegija Teorija i praksa organizacije informacija na diplomskom studiju Odsjeka za informacijske znanosti u Osijeku. Studenti su dio svoje praktične nastave iz navedenih kolegija odrađivali u knjižničnom informacijskom sustavu COBISS. Dodatni cilj rada je, stoga, bio prikazati način održavanja vježbi iz deskriptivne katalogizacije s aspekta edukatora, kao i iskustva studenata i edukatora prilikom korištenja i rada u sustavu COBISS.

\section{Zašto učiti kako učinkovito organizirati informacije?}

Osiguravanje pristupa informacijama izvorno je polazište i načelo knjižničarske i informacijske profesije. Ono se ostvaruje organizacijom i predstavljanjem informacija i znanja. I predstavljanje i organizacija informacija i znanja po svojoj su naravi iznimno složeni procesi obilježeni poteškoćama na koje je informacijska zajednica tijekom povijesti pronalazila različita rješenja (Špiranec i Ivanjko, 2012). Katalogizacija, koja je definirana kao postupak organiziranja informacija izradom bibliografskih zapisa na temelju pravilnika, poput Pravilnika za izradbu abecednih kataloga Eve Verone i MARC standarda, utvrđeni je postupak za postizanje navedenih ciljeva. Principi katalogizacije i brojni koncepti vezani za katalogizaciju, 
poput normativne i rječničke kontrole, iznimno su dragocjeni za unošenje reda u rastući informacijski univerzum (Holley, 2002). Kako navodi Joudrey (2008), katalogizacija te njeno podučavanje, kao i potreba za posredovanjem stručne osobe pri organizaciji informacija, kroz povijest je, ali i danas, u fazi neprestanih promjena i propitkivanja.

Naime, pojavom Google-a i Amazon-a informacijsko okruženje u kojem se traže i pretražuju informacije drastično se promijenilo. Prividna jednostavnost Google pretraživanja te njegovo brzo pretraživanje informacija čine ga zanimljivim alatom za korisnike koji nisu zainteresirani za sofisticirana pretraživanja te koji su zadovoljni s prihvaćanjem informacijskih izvora koji su »dovoljno dobri« (no, ne i nužno najbolji) za zadovoljavanje njihovih informacijskih potreba. Google Books projekt i Google Znalac, pokrenuti 2004. godine, također su proširili i opseg i vrstu informacijskih izvora kojima se može pristupiti, stoga ne čudi informacijsko ponašanje opće populacije koja se pri pretraživanju informacija najviše oslanja na tražilice poput Google-a (Hsieh-Yee, 2008). U vezi potonjeg, u radu autora Elroda (2008) oštro se kritiziraju implikacije da Google i Amazon mogu zamijeniti knjižnični katalog i katalogizaciju te ističe se kako je Google zapravo taj koji ograničava ljudsko posredovanje u organizaciji informacija naušrtb povećanja vlastite novčane dobiti. Miksa (2008) također diskutira o nelogičnosti usporedbe Google-a i tradicionalnog knjižničnog kataloga jer ih smatra različitim sustavima koji, iako dijele sličnu vanjsku svrhu, rade na temelju potpuno različitih unutarnjih procesa. Autor naglašava kako je u kurikulumima u kojima se podučava tradicionalna bibliografska kontrola vrlo bitno istaknuti važnost i stati u obranu knjižničnog kataloga u današnjem informacijskom okruženju sveprisutnih tražilica. Organizacija informacija, odnosno kvalitetna katalogizacija, danas i dalje ima vrijednost u smislu utjecaja na učinkovitost referentnih usluga, upravljanje zbirkama, dijeljenje izvora informacija te automatizaciju baza podataka (Morris i Wool, 1999). S druge strane, postoje praktičari i edukatori koji gledaju na uspjeh Google-a i Amazon-a te zaključuju kako knjižničarska i informacijska profesija jednostavno ne mogu njima parirati. Marcum (2006) tako u svom radu navodi uspjeh koji postiže Google pri pretraživanju, posebice među studentima, te dovodi u pitanje budućnost katalogizacije. Calhoun (2006) pak preporučuje ograničavanje katalogizacije samo na primarne izvore te smatra da organizaciju i opis ostalih vrsta izvora treba prepustiti izdavačima. Neki edukatori, poput Crowleya (2007), smatraju kako se knjižničarska i informacijska profesija trebaju usmjeriti isključivo na knjižnice i edukacijsku ulogu, dok poslove organizacije informacija treba prepustiti tražilicama.

Jasno je, dakle, kako unutar knjižničarske i informacijske profesije, a osobito unutar zajednice katalogizatora, postoje različita mišljenja i rješenja za velike promjene koje su se dogodile u novom informacijskom okruženju i informacijskom ponašanju korisnika. Razmišljanja i diskusije uglavnom se mogu svrstati pod tri ključna pitanja: Koje je naše poslanje? Koji je najučinkovitiji način obavljanja našega posla kojim bismo korisniku omogućili najbolje informacijske alate? Kako je potrebno pripremiti buduće praktičare, odnosno na koji način podučavati buduće generacije knjižničara i informacijskih stručnjaka? U sljedećem poglavlju pregledom literature pokušat će se dati odgovor na ova pitanja s posebnim osvrtom na edukaciju i obrazovanje budućih knjižničara i informacijskih stručnjaka.

\section{Katalogizacija kao temelj obrazovanja budućih informacijskih stručnjaka}

U članku »Why Teach Cataloguing and Classification?« Gorman (2002) ističe kako je organizacija informacija intelektualni temelj knjižničarske i informacijske profesije te da je bibliografska kontrola način na koji budući knjižničari i informacijski stručnjaci trebaju 
razmišljati. Dakle, za jednog knjižničara i informacijskog stručnjaka nije najbitnije poznavanje svih kataložnih pravila napamet koliko je bitno logično i kritičko razmišljanje, odnosno razumijevanje načina na koji su informacije (i znanje) organizirane za pretraživanje te komuniciranje toga znanja korisniku. Gorman u ovom kontekstu ističe kako je termin „metapodatak" proizašao zapravo iz želje onih koji su nastojali putem tražilica povećati pretraživost mrežnih stranica i ostalih dokumenata na mreži. S obzirom na to autor uspoređuje Dublinski osnovni skup elemenata metapodataka (Dublin Core), kojeg naziva kvazistandardom s premalo uključenih polja, s MARC (Machine-Readable Cataloging) knjižničnim standardom kojeg smatra pravim standardom za metapodatke. MARC je, osim što ima mnogo više polja i potpolja za upis metapodatka, puno bolji standard jer je razvijen na način ispunjavanja stvarnih karakteristika kompleksnih dokumenata svih vrsta (od primjerice knjiga do elektroničke građe). Kako je najvažnija stvar bibliografske kontrole sadržaj te njegova kontrola, upravo je MARC temeljni okvirni standard za bibliografske podatke i Dublinski skup ne može biti njegova zamjena (Gorman, 2002).

Također, brojni drugi istaknuti autori smatraju kako svi informacijski stručnjaci (ne samo knjižničari) trebaju znati kako pretraživati i pronaći informacije u online katalozima i bazama podataka, a to znanje je puno šire od poznavanja korištenja same tražilice poput Googlea. Na ovaj način bi informacijski stručnjaci, zahvaljujući razumijevanju strukture bibliografskog zapisa, kao i principa normativne kontrole te MARC formata, bili učinkovitiji u pretraživanju i pronalaženju informacija za sebe i za svoje korisnike (Holley, 2002; Normore, 2012). Mogućnost i vještine učinkovitog pretraživanja i pronalaženja informacija samo su jedan od ciljeva poslanja knjižničarske i informacijske profesije. Važan cilj u mrežnom okruženju koje je izazvalo promijenjeno informacijsko ponašanje korisnika je i implementacija inovativnih pristupa i tehnika u postojeće online knjižnične kataloge i baze podataka. Na taj način bi se i samom korisniku osigurao lakši i brži pristup informacijama i izvorima informacija. Primjer dobre prakse je EBSCO informacijski servis koji je u svojoj bazi indeksirao veliki broj članaka s cjelovitim tekstom te ponudio sadržajne kategorije i dodatne opcije pretraživanja kako bi pomogli korisnicima suziti rezultate pretraživanja. Također, brojni online knjižnični katalozi sve više nude mogućnost FRBR-iziranih zapisa te omogućavanje korisničkih oznaka ili tagiranja kako bi korisnik lakše identificirao izvore te došao do međusobno povezanih informacijskih izvora (Hsieh-Yee, 2008). lako je u online okruženju teže organizirati i upravljati informacijama te su shodno tome potrebnije i kompleksnije metode njihove organizacije, katalogizacija $i$ bibliografska kontrola i dalje ostaju vrlo dragocjeni postupci koji su srž informacijskih znanosti (Indiana University, Task Group on the Future of Cataloging, 2006).

\subsection{Kurikulum za kolegije iz organizacije informacija i katalogizacije: pregled literature}

Tema obrazovanja i edukacije knjižničarskih i informacijskih stručnjaka bila je u fokusu mnogih članaka i autora tijekom proteklog stoljeća, ali je aktualna i danas. Rasprave su se uglavnom vodile oko kurikuluma te oko omjera teorije i prakse koji treba biti uključen u kolegije. Brojna istraživanja se bave raznim perspektivama ove teme od perspektive poslodavaca $u$ knjižnicama, edukatora u knjižničarskim školama te fakultetima pa sve do perspektive i mišljenja samih studenata koji studiraju informacijske znanosti. Kako se knjižničarstvo kao grana informacijskih znanosti nastavlja ubrzano razvijati, jedno od područja obilježeno izraženim promjena je upravo područje katalogizacije. Uz rastući broj novih vrsta izvora koji su se pojavili u online okruženju, postavlja se pitanje jesu li budući informacijski stručnjaci koji se zapošljavaju adekvatno pripremljeni za obavljanje svoga posla. U nastavku je, stoga, dan 
pregled literature o različitim pogledima na ulogu edukacije i podučavanja katalogizacije te njenog položaja u kurikulumu studija na kojima se podučava.

Kao što je prethodno spomenuto, najveći dio radova u vezi s podučavanjem katalogizacije bavi se omjerom teorije i prakse koji treba biti uključen u kolegije organizacije informacija. Osim ove teme, aktualna tema u literaturi je i uloga katalogizacije i organizacije informacija u kurikulumu. Leonard i Pontau (1991) u svom radu pružaju korisnu povijesnu perspektivu podučavanja katalogizacije, ukazujući na pedagoški pomak u naglašavanju teorije u odnosu na praktično iskustvo koji se dogodio u 20. stoljeću. Spillane (1999) i Saye (2002) također daju povijesni pregled obrazovanja budućih katalogizatora, pri čemu naglašavaju kako je očiti opadajući interes za katalogizaciju uzrokovan smanjenjem obveznih kolegija na kojima se uči katalogizacija, kao i općenitim padom promocije knjižničarske i informacijske profesije kao karijere na fakultetima. Studija koju su među diplomiranim studentima proveli MacLeod i Callahan (1995) jasno pokazuje kako diplomanti žale što tijekom studiranja na kolegijima na kojima se uči katalogizacija nisu dobili više praktične nastave i prakse općenito. Slične je rezultate $u$ vezi s praktičnom nastavom pokazala i studija provedena među iskusnim katalogizatorima koji smatraju kako bi praktična nastava trebala biti obvezna u kurikulumu informacijskih znanosti (Damasco i McGurr, 2008). Izazov stvaranja uspješnog kurikuluma kolegija na kojima se podučava katalogizacija dodatno je zakomplicirana i dinamičnom prirodom same katalogizacije. Hsieh-Yee (2008) i Joudrey (2008) ističu kako se upravo zbog toga neprestano širi popis tema koje je potrebno uključiti na kolegije o katalogizaciji (primjerice metapodatci, MARC, novi pravilnici i standardi i slično), što može biti prenaporno i za studente i za edukatore. Joudrey (2008) je također napravio pregled literature o organizaciji informacija i katalogizaciji za obrazovanje i edukaciju informacijskih stručnjaka u Sjevernoj Americi od 1990. - 2001. godine, dok je urednica knjige Education for Cataloging and the Organization of Information: Pitfalls and the Pendulum Hill (2013) objedinila 22 članka u kojima se naglašavaju različiti aspekti edukacije i obrazovanja informacijskih stručnjaka pri podučavanju organizacije informacija.

Interes za dobrom edukacijom i pripremom novih katalogizatora za budući posao imaju i poslodavci i edukatori i studenti. Nekoliko studija ukazalo je na potrebu povećanja suradnje između knjižničnih škola te fakulteta i poslodavaca u informacijskim ustanovama kako bi se osigurala dobra priprema studenata za buduće karijere. Istraživanja su pokazala kako poslodavci smatraju da kolegiji na kojima se uči katalogizacija nisu dovoljni za pripremu početnika za posao (MacLeod i Callahan, 1995; Hall-Ellis, 2005). Brojne studije tako ističu potrebu za uravnoteženim pristupom u obrazovanju katalogizatora koje će studentima pružiti mogućnost primjene teorijskog znanja u svakodnevnim praktičnim zadacima na poslu (Letarte et al., 2001; Turvey i Letarte, 2002).

\subsection{Kako treba izgledati učinkovit praktikum iz katalogizacije?}

Većina studenata koji studiraju informacijske znanosti ili njihovu granu knjižničarstvo upoznali su se s katalogizacijom tijekom pohađanja kolegija u sklopu svoga fakultetskog obrazovanja. To je također jedan od najizazovnijih predmeta za podučavanje. Katalogizacija je složen predmet, a učenje studentima može biti teško jer se moraju upoznati s velikom količinom složenih sadržaja. Studenti ne trebaju svladati samo teorijska znanja, nego i primjenu kataložnih pravilnika i standarda za izradu kataložnog opisa. Sva potrebna znanja i vještine trebaju se moći uspješno prenijeti studentima kroz kolegije na kojima se katalogizacija 
podučava. Stoga su se edukatori godinama trudili pronaći najbolje načine kako bi proces prenošenja znanja učinili što uspješnijim. Međutim, svaki edukator mora biti svjestan da svaki student, ali i edukator, ima različite načine, odnosno stil učenja i stil rada. Posljednjih godina istraživači u obrazovanju sve više se fokusiraju na različite aspekte stilova učenja te kako se oni mogu primijeniti u obrazovanju. Uključivanje stilova učenja u nastavne planove može olakšati učenje i dovesti do boljeg postignuća studenta. Nadalje, studenti koji imaju jaku sklonost određenom stilu učenja mogu imati poteškoće ako se stil podučavanja ne podudara $s$ preferiranim stilovima učenja. Jedan od poznatih modela je i Felder-Silvermanov model stilova učenja (FSLSM). Model omogućava preciznu kvantitativnu procjenu sklonosti studenta na diskretnoj skali uzduž četiri dimenzije: aktivno/refleksivna (prema obradi primljene informacije), racionalno/intuitivna (prema tipu informacije kojeg bolje usvajaju), vizualno/verbalna (prema preferiranim perceptualnim tendencijama) i sekvencijalno/globalna (prema napredovanju u razumijevanju sadržaja). Tako, primjerice, student sklon aktivnom učenju više je zainteresiran za razgovor s drugima i voli raditi u grupama za razliku od studenata koji preferira refleksivnu dimenziju učenja. Primjerice, edukatoru bi bilo bitno znati ima li više studenata na vježbama katalogizacije koji su vizualni tipovi ili verbalni kako bi lakše priredio materijale za nastavu (Graf et al., 2007). U kontekstu ovog modela, valja reći kako je istraživanje Rineharta, Sharkeya i Kahla (2015) rađeno prema ovom modelu pokazalo da postoje neke razlike između stilova učenja koje imaju katalogizatori spram ostalih knjižničara. Dimenzije u kojima su katalogizatori imali utvrđene statističke razlike su: refleksivno učenje, racionalno učenje i sekvencijalno učenje. Također, tu je Hermannov instrument s četiri kvadranta u koja su raspoređeni preferirani stilovi razmišljanja studenata. Kvadrant A je, primjerice, povezan s logičnim i analitičkim razmišljanjem, a studenti najbolje reagiraju na, primjerice, formalna predavanja. U kvadrant B studenti najbolje uče vrednovanjem i testiranjem teorija, dok je kvadrant $C$ obilježen timskim radom i dijeljenjem ideja. Kvadrant $D$ je obilježen intuitivnošću i preuzimanjem inicijative, a studenti najbolje reagiranju, primjerice, na spontanost i zaigranost (Petr, 2008). Što se tiče sklonosti načina razmišljanja potrebnih za uspjeh prilikom izvršavanja zadataka iz katalogizacije, prema Coetzeeu i de Boeru (2000) potrebne su sljedeće kompetencije: analiziranje, rješavanje problema, provedba i organizacija. Bibliografska organizacija i kontrola oslanjaju se uveliko na tehničko znanje i stručnost. Njihova studija je otkrila da su studenski preferirani stilovi razmišljanja bili povezani prvenstveno $\mathrm{s}$ kvadrantom C (snažna sklonost međuljudskim odnosima, osjećajima, emocijama i načini duhovnog razmišljanja) i B (kontrolirani, strukturirani i organizirani strukturirani modeli).

Osim stilova učenja i preferiranih načina razmišljanja, edukatori trebaju biti i poprilično pažljivi i selektivni pri odabiru sadržaja i praktičnih zadataka jer postoji naravno ograničenje koliko gradiva student može usvojiti tijekom vremenskog razdoblja izvođenja kolegija. Tempo i vrijeme kolegija na kojem se uči katalogizacija moraju se dobro razmotriti. Sadržaj također treba predavati na način koji omogućava studentima graditi vještine katalogiziranja, a da ih se istovremeno ne zatrpava s previše zadataka. Usto, za razliku od ostalih kolegija u nastavnom programu, edukatori se često susreću sa studentskom anksioznošću zbog polaganja ispita iz katalogizacije. Edukatori često moraju biti inovativni, predstavljajući katalogizaciju kao zabavnu i izvedivu kako bi uvjerili studente da mogu savladati kolegij. Kako bi studentima pomogli pri učenju katalogiziranja, profesorima koji predaju katalogizaciju je važno razviti najučinkovitije osnovne metode za početnike koje promiču učenje (Snow i Hoffman, 2015). Trenutne rasprave $u$ literaturi o tome što ima najbolji učinak na studente koji uče 
katalogizaciju uglavnom su anegdotske, odnosno iz iskustva dugogodišnjih edukatora (Intner, 2002; Holley, 2002; Miksa, 2008). Autorica Intner (2002) navodi, primjerice, kako postoji veza između količine praktičnih zadataka koje studenti rješavaju na nastavi ili za zadaću i sposobnosti studenata da usvoje postupke katalogizacije. Međutim, to ne znači nužno i razumijevanje kataložnih principa i načela koji su potrebni za dobru prosudbu katalogizatora te za fleksibilnost i proaktivnost u promjenjivom radnom okruženju. Ono što je prema autorici krucijalno je pitanje koje neprestano treba postavljati svaki edukator »koja je svrha ovoga što radimo?«.

S druge strane, mišljenje studenata o tome kako trebaju izgledati kolegiji iz katalogizacije istraživano je u studiji Al Hijji i Fadlallah (2013). Ova studija je pokazala kako studenti informacijskih znanosti žele više prakse, veće sudjelovanje stručnjaka za katalogizaciju te više praktičnog iskustva u korištenju knjižničnih sustava, korištenju alata za katalogizaciju i izradi bibliografskih zapisa na samoj nastavi. Slične rezultate pokazala je i studija Damasca i McGurra (2008). U ovom kontekstu bitno je izdvojiti i noviju studiju Snowa i Hoffmana (2015) koja izdvaja četiri elementa koji čine razliku i utječu na studentsko učenje katalogizacije. Prvi je element što više kataložne prakse. Primjerice, neki studenti su izjavili kako su uz pomoć praktičnih primjera uspjeli shvatiti teoriju te izrazili kako im je potrebno više edukacije vezane za MARC formate. Kao drugi element izdvaja se učinkovitost edukatora, pri čemu važne karakteristike uključuju entuzijazam i strast prema katalogizaciji, sposobnost pružanja jasnih objašnjenja, posjedovanje praktičnog kataložnog znanja i davanje puno povratnih informacija. Element ravnoteže teorije i prakse većina studenata navodi u smislu učenja primjene teorije na praktičnim primjerima. Primjerice, studenti smatraju kako je potrebno da ih se nauči kako upotreba različitih načina pretraživanja kataloga utječe na rezultate pretraživanja, kako određeno polje u MARC-u utječe na rezultate pretraživanja, kako predvidjeti informacijsko ponašanje korisnika pri pretraživanju kataloga i slično. Na navedeno se nadovezuje i posljednji element, a to je upotreba i primjena katalogizacije u kontekstu »stvarnih situacija (primjerice, stavljanje u kontekst rada u knjižnici pokazujući kako katalogizacija može pomoći korisniku, pokazivanje primjera u lokalnom online katalogu, rad u knjižničnom sustavu tako da studenti mogu vidjeti kako izgleda zapis u MARC formatu i slično). Potrebno je, dakle, da edukator da "cjelovitu sliku«, odnosno da nauči studente ne samo kako katalogizirati, već i zašto katalogizirati.

\subsection{Poželjna znanja i vještine koje bi trebao imati budući informacijski stručnjak}

Kako bi se razumijevale promjene koje su se dogodile u knjižničarskoj i informacijskoj profesiji, potrebno je razumjeti trendove koji su utjecali na katalogizaciju, odnosno na kompetencije koje su poželjne kod budućih katalogizatora te načine na koji se mogu i trebaju pripremati za uspješnu karijeru. Prvi kongres o profesionalnom obrazovanju Američkog knjižničarskog društva iz 1999. godine bavio se temom početničke edukacije knjižničara s različitih aspekata, uključujući temeljne vrijednosti, srž kompetencija, akreditacije i stratifikacije (ALA, 1999). Međutim, s novim elektroničkim okruženjem informacijski stručnjaci morali su preispitati svoje vještine i znanja te redefinirati svoju ulogu. Promjene koje su se dogodile su brojne, a neke od njih su: utjecaj tehnologije (automatizacija, tehnološki napredak, rast elektroničkih izvora), smanjenje proračuna koje dobivaju informacijske ustanove i povećani zahtjevi za informacijskim uslugama (promjena korisničkih potreba, posebno povećana očekivanja u vezi sa izvorima u elektroničkim formatima), promjene u znanstvenom radu i praksi i slično. Promjena uloge profesionalnog informacijskog stručnjaka zahtijeva težnju razvijanja niza 
vještina: od tradicionalnih vještina i znanja katalogizacije poput poznavanja bibliografske kontrole, predmetne analize, normativne kontrole, MARC zapisa, kataložnih pravila, sustava klasifikacije do niza potpuno novih vještina.

Računalne vještine, komunikacijske vještine, vještine podučavanja i poznavanje standarda metapodataka koji nisu MARC prema Glasseru (2007) smatraju se potrebnim vještinama za zadatke koje danas obavljaju profesionalni informacijski stručnjaci. Dodatnim vještinama se smatraju fleksibilnost, sposobnost i spremnost za stalno i brzo učenje, tolerancija za promjene, fokus na korisničku uslugu i sposobnost rada u timskom okruženju. Mering (1998) naglašava potrebu za fleksibilnošću, upoznavanjem s tehnologijama, spremnošću za preuzimanje različitih zadaka te sposobnost podučavanja kao važnih vještina i karakteristika današnjih informacijskih stručnjaka. Autorica također ističe potrebu za shvaćanjem utjecaja radnih zadataka i odgovornosti na druga područja u informacijskoj ustanovi, primjerice utjecaj kvalitetnog kataložnog zapisa na izravno isporučenu uslugu krajnjem korisniku. Na ovu temu potrebno je spomenuti još dva važna istraživanja. Prvo je istraživanje Letartea et al. iz 2001. godine o kompetencijama katalogizatora u visokoškolskim knjižnicama koje je pokazalo kako je najvažnija kompetencija prema mišljenju ispitanika sposobnost čitanja i interpretacije bibliografskog zapisa u OPAC-u. Ova kompetencija zapravo obuhvaća široko znanje deskriptivne i predmetne katalogizacije te znanje o standardima i alatima za katalogizaciju. Osim navedenog, ova sposobnost obuhvaća i kompetencije koje se odnose na način kako je OPAC strukturiran te kako olakšati pretraživanje. Za informacijskog stručnjaka je, dakle, bitno razumjeti koncept izrade baze podataka, izrade zapisa u bazi te kako najučinkovitije uz pomoć znanja katalogizacije pretraživati i pronaći informacije. Drugo istraživanje je autora Chaudhrya i Komathia (2002) u kojem su se na temelju analize oglasa za posao ispitivale razlike poslodavaca u zahtjevima znanja i vještina katalogizatora u elektroničnom okruženju $\mathrm{s}$ obzirom na tradicionalno. Iz oglasa su izdvojene vještine poznavanja kataložnih alata i izvora (automatiziranih kataložnih sustava) kao najbitniji zahtjev, uz dodatne IT vještine (računalne vještine) kao sekundarni zahtjev. Poznavanje interneta i digitalnih sustava te komunikacijske vještine su također jako bitne u elektroničnom okruženju za poslodavce. Ukupno gledajući, uloga katalogizatora i zahtjevi koji se pred njih postavljaju se proširuju, naročito u području menadžerskih vještina i vještina stručnjaka koji održavaju sustave, no i dalje znanje iz područja kataložnih alata i izvora ostaje osnovni zahtjev poslodavaca.

Osim spomenutog Američkog knjižničarskog društva, koje je kasnije revidiralo ključne kompetencije knjižničara dokumentom iz 2009. godine (ALA, 2009), važno je spomenuti najnoviji dodatak ovom dokumentu koji je izašao 2017. godine pod nazivom Core Competencies for Cataloging and Metadata Professional Librarians (ALCTS Board, 2017). Iz samog naziva dokumenta jasno je kako su se ključne kompetencije knjižničnih i informacijskih stručnjaka prilagodile novom elektroničnom okruženju. Ključne kompetencije su tako podijeljene u tri najšire kategorije: kompetencije vezane uz znanje, kompetencije vezane uz vještine i sposobnosti te kompetencije vezane uz ponašanje. Kompetencije vezane uz znanje uključuju razumijevanje konceptualnih modela na kojima se temelje standardi i strukture osnovnih alata za katalogizaciju i standarda kodiranja. Dijele se u tri glavna područja: načela, sustavi i tehnologija te trendovi. Načela podrazumijevaju poznavanje temeljnih načela i standarda za sadržaj bibliografskih podataka (na primjer AACR, LCC, MARC, LRM i slično). Sustavi obuhvaćaju načine upravljanja bibliografskim podacima (na primjer Koha, WorldCat, OCLC Connexion i slično). Poznavanje trendova u katalogizaciji i struci metapodataka uključuju 
nove alate i standarde, kao i razumijevanje kako se katalogizacija uklapa u širi svijet knjižnica (na primjer povezani podaci, PCC, Upravni odbor RDA-a i slično). Druga kategorija su kompetencije vezane uz vještine i sposobnosti. One uz sposobnost ovladavanja pojedinačnim načelima i vještinama obuhvaćaju i sintezu tih principa i vještina za stvaranje ujednačenih, usklađenih bibliografskih podataka koji funkcioniraju u lokalnim i međunarodnim ekosustavima metapodataka. Pod ovim se podrazumijeva primjena konceptualnih okvira, standarda i principa u bibliografskom sustavu, primjena univerzalnih standarda u lokalnom kontekstu te integracija, mapiranje i transformacija metapodataka unutar bibliografskog sustava. Posljednje poželjne kompetencije jednog informacijskog stručnjaka odnose se na kompetencije vezane uz ponašanje, a podrazumijevaju osobne osobine koje doprinose uspjehu u profesiji i načinima razmišljanja. Izdvojene osobine su: međuljudska komunikacija, orijentacija na javne službe, inicijativa i prilagodljivost, profesionalna znatiželja i sposobnost za rješavanje problema (ALCTS Board, 2017).

\section{Podučavanje organizacije informacija i katalogizacije na Odsjeku za informacijske znanosti u Osijeku}

Odsjek za informacijske znanosti u Osijeku, uz Zagreb i Zadar, jedan je od tri vodeća odsjeka/odjela u Hrvatskoj iz područja knjižnične i informacijske znanosti na kojima se podučava katalogizacija. Današnji Odsjek za informacijske znanosti na Filozofskom fakultetu u Osijeku izrastao je iz Katedre za knjižničarstvo tadašnjeg Pedagoškog fakulteta u Osijeku koja je počela s radom akademske godine 1998./1999. na dva studija: redovnom dodiplomskom dvopredmetnom (četverogodišnjem) studiju knjižničarstva i dopunskom dvogodišnjem izvanrednom studiju knjižničarstva u trajanju od dvije godine. Prelaskom na bolonjski sustav obrazovanja oba su se studija ugasila, a Katedra za knjižničarstvo prerasla je u Odsjek za informacijske znanosti. Studijski programi su potom 2015. godine izmijenjeni na diplomskoj razini te je danas u dvopredmetnoj kombinaciji moguće studirati diplomske studije informatologije, informacijske tehnologije i nakladništva. Pri izradi kurikuluma Odsjek za informacijske znanosti vodio se raznim preporukama međunarodnih institucija i udruženja (primjerice IFLA, ASIST, IPA), kao i preporukama o temeljnim kompetencijama informacijskih stručnjaka (CILIP, NORDINFO, ECIA). Odsjek se u svom radu i radu sa studentima iznimno oslanja na modernu IT tehnologiju, naročito na WebCT i Moodle te na taj način nudi studentima moderan i napredan pristup stjecanju novih znanja i vještina (Odsjek za informacijske znanosti, 2020a). U ožujku 2020. godine uslijed situacije uzrokovane pandemijom koronavirusa nastava je održavana online putem BigBlueButton softvera. Pored raznih usluga mrežnih konferencija, sustav posjeduje integracije za sustave za online učenje $i$ upravljanje sadržajem putem kojeg su se izvodile i vježbe iz deskriptivne i strojno čitljive katalogizacije iz kolegija Organizacija informacija I i Teorija i praksa organizacije informacija.

Podučavanju katalogizacije i klasifikacije na Odsjeku se uvijek poklanjala pažnja i važnost u nastavnom programu (i stari i novi) s obzirom da ih se smatra temeljem profesije. Imajući na umu da studenti preddiplomskog studija možda neće moći razumjeti složenost i raznolikost tema, teme vezane uz katalogizaciju i klasifikaciju u starom kurikulumu uvodile su se postepeno. Slijedom toga, kolegiji na kojima se uči katalogizacija bili su odvojeni od kolegija na kojima se uči klasifikacija te raštrkani kroz sve četiri godine kako bi se postepeno mogli predstaviti studentima. U starom kurikulumu tako su se izvodili sljedeći kolegiji na kojima se podučavala katalogizacija i klasifikacija: Uvod u bibliografsku organizaciju, Bibliografska 
organizacija i kontrola (1 i 2), Uvod u klasifikacijsku teoriju i sustave, Knjižnični klasifikacijski sustavi te Sustavi za indeksiranje i pretraživanje. Deskriptivna i strojno čitljiva katalogizacija učila se na tri navedena kolegija, Uvod u bibliografsku organizaciju te Bibliografska organizacija $i$ kontrola 1 i 2 . Na kolegiju Uvod u bibliografsku organizaciju studente se pripremalo za deskriptivnu katalogizaciju te su tako učili razlikovati različite vrste građe, dijelove knjige, različite standarde, informacijske izvore i slično. Kolegiji Bibliografska organizacija i kontrola 1 u cijelosti je pokrivao temu deskriptivne katalogizacije. Studenti su na navedenom kolegiju učili kako katalogizirati monografske publikacije, serijske publikacije, višesvešćane publikacije, neknjižnu i elektroničku građu. Kataložna praksa se u Hrvatskoj temelji na Pravilniku Eve Verone te se uz Pravilnik za podučavanje katalogizacije na Odsjeku koriste i IFLA-ini ISBD standardi s obzirom na ostale materijale koji nisu monografski. Kolegiji Bibliografska organizacija i kontrola 2, koji se izvodio dvosemestralno, bio je posvećen učenju o bibliografijama te učenju katalogizacije u UNIMARC formatu. Na ovaj način studenti su ponavljali stečeno znanje iz deskriptivne katalogizacije na prethodno navedenim kolegijima te ga nadograđivali upoznajući se sa strukturama baza podataka i koristeći MARC format za strojno čitljivu katalogizaciju (Petr, 2008). Ostali navedeni kolegiji pokrivali su teme iz klasifikacije i klasifikacijskih sustava o kojima se u ovome radu neće govoriti.

Nakon Bolonjskog procesa, novi kurikulum je doživio poprilične stukturalne i sadržajne promjene. Preddiplomski studij sada traje tri godine, diplomski dvije, a dvosemestralnih kolegija više nema u kurikulumu. Također, kao što je već spomenuto, moguće je studirati u dvopredmetnoj kombinaciji diplomske studije informatologije, informacijske tehnologije $i$ nakladništva pri čemu se deskriptivna i strojno čitljiva katalogizacija uče samo na studiju informatologije. Paralelno $s$ promjenama koje je donio Bolonjski proces i trendovima $u$ knjižničnim školama u svijetu, Odsjek je odlučio da se u novom kurikulumu više neće odvajati kolegiji katalogizacije i klasifikacije. U tablici 1 i 2 popisani su kolegije u novom kurikulumu studija informatologije na kojima se uči katalogizacija, klasifikacija i predmetno označivanje (Petr, 2008).

Tablica 1: Kolegiji preddiplomskog studija na kojima se podučavaju kolegiji iz organizacije informacija

\begin{tabular}{lllll}
\hline Preddiplomski studij & $\begin{array}{l}\text { Kreditne } \\
\text { točke }\end{array}$ & Predavanja & Vježbe & Seminar \\
\hline $\begin{array}{l}\text { Uvod u knjižničnu i informacijsku } \\
\text { znanost }\end{array}$ & 6 ECTS & 30 & 30 & 30 \\
\hline Organizacija informacija 1 & 6 ECTS & 30 & 60 & - \\
\hline Organizacija informacija 2 & 6 ECTS & 30 & 30 & - \\
\hline Metapodaci i identifikatori & 5 ECTS & 30 & 30 & - \\
\hline
\end{tabular}

Tablica 2: Kolegiji diplomskog studija na kojima se podučavaju kolegiji iz organizacije informacija

\begin{tabular}{llll}
\hline Diplomski studij & Kreditne točke & Predavanja & Vježbe \\
\hline Teorija i praksa organizacije informacija & 3 ECTS & 30 & 30 \\
\hline Predmetno označivanje i pretraživanje & 3 ECTS & 30 & 30 \\
\hline
\end{tabular}

Na kolegiju Uvod u knjižničnu i informacijsku znanost (prva godina preddiplomskog studija) studenti se na vježbama pripremaju za deskriptivnu katalogizaciju kao kroz prethodno 
spomenuti kolegiji Uvod u bibliografsku organizaciju, ali uz jednu iznimku. Naime, prije nekoliko godina, profesori koji predaju na kolegiju Organizacija informacija 1 (koji slijedi na drugoj godini preddiplomskog studija) zaključili su kako je cjelokupno gradivo vezano za deskriptivnu i strojno čitljivu katalogizaciju koje je studentima potrebno prezentirati na praktičnim vježbama preopširno za samo jedan kolegiji. Stoga je odlučeno da se dio gradiva (podučavanje pristupnica) iz praktičnih vježbi kolegija Organizacija informacija 1 prebaci na kolegiji Uvod u knjižničnu i informacijsku znanost na prethodnu godinu studija. Na drugoj godini preddiplomskog studija slijede, dakle, kolegiji Organizacija informacija 1 i 2 . Organizacija informacija 1 je središnji kolegij na kojem se na vježbama izučava deskriptivna i strojno čitljiva katalogizacija (ručno te uz pomoć knjižničnih računalskih programa) čiji je detaljan opis dan u sljedećem poglavlju. Na teorijskim predavanjima studenti se pak upoznaju sa ciljevima bibliografske organizacije, svrhom, načelima i problemima organiziranja bibliografsko-kataložnih informacija, kao i vrstama entiteta u bibliografskim sustavima: dokumentima, djelima, nad-djelima i izdanjima. Također, upoznaju se i s knjižničnim referentnim modelom IFLA LRM te diskutiraju o problemima utvrđivanja autorstva $u$ knjižničnim katalozima. Kolegij Organizacija informacija 2 pokriva gradivo o najvažnijim postavkama vezanim uz sadržajnu obradu građe, s posebnim osvrtom na teoriju klasifikacije te različite vrste klasifikacijskih shema (UDK, DDC, LCC, BC i slično), dok na vježbama uče klasificirati dokumente uz pomoć UDK klasifikacijske sheme. Kolegij Metapodaci i identifikatori ima za cilj upoznati studente s razvojem metapodataka i njihovom ulogom u oblikovanju, organizaciji, zaštiti i održavanju elektroničkih dokumenata i e-poslovanja te ih osposobiti da prepoznaju složenije elemente XML-a, RDF-a, ovladaju elementima Dublinskog skupa, DOI-a i srodnih sustava te koriste metapodatke pri izradi laganijih zadaća pomoću generatora metapodataka. Posljednja dva kolegija na diplomskom studiju na kojima se izučavaju katalogizacija i klasifikacija su kolegiji Predmetno označivanje i pretraživanje i Teorija i praksa organizacije informacija. Prvi navedeni se prvenstveno bavi teorijskim radovima i praktičnim postignućima u polju pretraživanja informacija te predmetnom katalogizacijom i pristupnom sadržaju. U sklopu kolegija Teorija i praksa organizacije informacija studenti produbljuju svoja teorijska znanja o konceptualnim sustavima za organizaciju informacija (FRBR, CIDOC CRM, FRBRoo, PRESSoo, IFLA LRM) te na teorijskim predavanjima uče o metapodatkovnim shemama, reprezentaciji znanja u knjižničnoj zajednici i podatkovnoj kontroli. Na praktičnim vježbama studenti ponavljaju stečeno znanje iz deskriptivne i strojno čitljive katalogizacije $s$ druge godine studija te se upoznaju s opisivanjem različitih vrsta knjižnične građe (zemljovidi, elektronička građa, stara i rijetka građa i slično), pitanjima granularnosti u opisu na razini zbirke. Za strojno čitljivu katalogizaciju koriste različite knjižnične sustave (CROLIST, Qulto), a akademske godine 2019./2020. (vježbe su izvođene uživo) i 2020./2021. (vježbe su izvođene online) prvi puta je studentima predstavljen knjižnični sustav COBISS u kojem su praktične vježbe odrađivali cijelo trajanje pandemije uzrokovane koronavirusom (Odsjek za informacijske znanosti, 2020b). U nastavku rada, stoga, slijedi opis jednoga sata vježbi iz deskriptivne i strojno čitljive katalogizacije iz perspektive edukatora.

\subsection{Kako izgleda jedan sat vježbi (uživo i virtualno) iz deskriptivne katalogizacije: perspektiva edukatora}

Sam termin katalogizacija odnosi se, tj. obuhvaća deskriptivnu katalogizaciju, predmetnu katalogizaciju te klasifikaciju. $U$ ovom radu, a posebice u ovom poglavlju, bavimo se isključivo deskriptivnom katalogizacijom, odnosno opisom jednog sata praktičnih vježbi i općenito 
metodama podučavanja studenata tokom izvođenja istih. Kao što je već spomenuto, deskriptivna katalogizacija se na Odsjeku podučava na kolegijima Uvod u knjižničnu $i$ informacijsku znanosti, Organizacija informacija 1 i Teorija i praksa organizacije informacija. U akademskoj godini 2019./2020. vježbe iz katalogizacije održane su uživo, a studenti su u drugom dijelu semestra strojno čitljivu katalogizaciju obavljali u dva knjižnična sustava, CROLIST-u i COBISS-u. Akademske godine 2020./2021. tijekom pandemije praktična nastava iz kolegija Organizacija informacija 1 i Teorija i praksa organizacije informacija održana je u potpunosti online. Vježbe iz deskriptivne katalogizacije održane su putem sustava BigBlueButton. Knjižnični informacijski sustav koji se koristio za učenje strojno čitjive katalogizacije je sustav COBISS. Razlozi su fleksibilnost i dobro prihvaćanje od strane studenata prethodne akademske godine te mogućnost rada i pristupa sustavu online putem interneta (za razliku od CROLIST-a za čiji je pristup potrebno biti fizički prisutan na fakultetu). Na ovaj način studenti su mogli raditi praktične zadatke u virtualnoj učionici (putem BigBlueButton-a) uz prisustvo edukatora te također izrađivati zadatke za vježbu od kuće.

Kao što je već spomenuto u prethodnom poglavlju, dio nastave iz praktičnih vježbi s kolegija Organizacija informacija $1 \mathrm{~s}$ druge godine preddiplomskog studija prebačeno je zbog opširnosti sadržaja na vježbe iz kolegija Uvod u knjižničnu i informacijsku znanost na prvoj godini preddiplomskog studija. S obzirom da je riječ o studentima prve godine preddiplomskog studija koji se tek upoznavanju s vrstama publikacija, osnovnim elementima knjige i njenog opisa, iz gradiva vježbi kolegija Organizacija informacija 1 prebačeno je gradivo u kojem se uči o katalogu te pristupnicama (odrednice i redalice). Stoga, od ukupno 30 sati praktičnih vježbi na kolegiju Uvod u knjižničnu i informacijsku znanost od 12 do 14 sati vježbi sada pokriva gradivo u kojem studenti uče o katalogu (povijest, vrste i svrha) te vrstama i izradi pristupnica.

Što se tiče načina podučavanja i metoda koje se koriste da bi studenti shvatili za što im služi određivanje autorstva za neko djelo te izrade pristupnica, najčešće se koriste primjeri iz stvarnoga života. Primjerice, studentima se pokaže primjer samoslike makaki majmuna oko kojeg se vodio pravni slučaj u vezi sa autorskim pravima za navedenu sliku. Sa studentima se diskutira o tom slučaju te autorstvu fotografije, a potom se daju i različiti drugi primjeri određivanja autorstva poput predsjedničkog govora, korespondencije dva autora, pisanja djela pod pseudonimima, reda predavanja na fakultetu i slično. Nakon što edukator za svaku vrstu pristupnice prođe kroz prezentaciju tijekom čijeg izlaganja za svako pravilo iz Pravilnika Eve Verone daje dodatne primjere, studenti pristupanju rješavanju zadataka na satu. Praktični zadaci su u najvećoj mjeri vezani za vrstu pristupnice koju uče taj dan na vježbama, a materijali na kojem rade su primjeri naslovnih stranica omeđenih publikacija (monografske građe). lako prije samog učenja pristupnica studenti uče o dijelovima knjige i elementima opisa (naslov, vrste stvarnih naslova, podnaslov, impresum, kolofon) koji su kasnije bitni za učenje kataložnog opisa, edukator je na ovom uvodnom kolegiju usmjeren isključivo na studentsko shvaćanje autorstva. Iskustvo je pokazalo kako studenti prve godine još uvijek nisu u stanju povezati sve informacije koje uče, poput elemenata opisa knjige, s potpunim bibliografskim zapisom. Stoga je prvi cilj vježbi ovog uvodnog kolegija pripremiti studente za deskriptivnu katalogizaciju na način da znaju prepoznati osnovne elemente opisa građe koji će im poslije biti potrebni za izradu cjelokupne strukture bibliografskog zapisa.

Drugi, još važniji cilj je naučiti ih odgovoriti na pitanje »tko je autor?«, odnosno o kojoj vrsti pristupnice je riječ. Edukator često naglašava kako je određivanje autorstva, odnosno 
prepoznavanje pristupnice, slično »matematičkom zadatku« pošto su pravila iz Pravilnika jasna i primjenjiva. Ono što je pak zamijećeno tijekom podučavanja pristupnica je studentska odbojnost prema učenju pravila napamet te teškoće sa shvaćanjem korporativnog autorstva. Metoda koja se pokazala učinkovitom u ovom slučaju je zadatak gdje studenti na internetu putem svojih mobilnih uređaja trebaju pronaći konferenciju (redni broj, mjesto na kojem je održana i godina održavanja) na kojoj je edukator imao izlaganje. Potom, pronađen naziv konferencije prema kriteriju pretraživanja sautor« trebaju potražiti u online knjižničnom katalogu. Na sličan način pretražuju katalog i za ostale vrste pristupnica, a cilj je naučiti ih čemu služi katalog (ili bilo koja baza podataka) te koja je svrha deskriptivne katalogizacije (ili bilo kojeg metapodataka). Studenti također imaju i zadaće koje izrađuju kod kuće, a koje uključuju pronalaženje primjera naslovnih stranica za svaku vrstu pristupnica. Zadaća se sastoji od slika stranica (naslovne, preliminarnih i slično) fizičke jedinice građe iz knjižnice koje su najčešće slikane mobilnim uređajem i koje su im bile potrebne da bi odredili pristupnicu, potom od slike bibliografskog zapisa iste jedinice građe s ekrana računala iz online kataloga knjižnice, označivanja i isticanja autora na slici bibliografskog zapisa te na koncu izrade same pristupnice prema Pravilniku.

Na drugoj godini preddiplomskog studija slijedi kolegij Organizacija informacija 1 koji je središnji kolegij na kojem se podučava katalogizacija kroz 60 sati praktičnih vježbi (4 školska sata tjedno). Nakon uvodnih vježbi na kojima se studentima objasni svrha kolegija, sa studentima se ponavlja gradivo. Ponavljanje gradiva o vrstama i svrsi kataloga edukator na drugoj godini preddiplomskog studija ne radi više formalnom prezentacijom nego pomoću online knjižničnog kataloga. Naime, edukator na temelju kriterija pretraživanja (po autoru, naslovu, ključnim riječima, predmetu i slično) u tražilici online kataloga objašnjava kako je online katalog zapravo spoj svih vrsta kataloga. Na taj način se studentima približava razlika između formalnih kataloga i deskriptivne katalogizacije te stvarnih kataloga i predmetne katalogizacije. Cilj navedenog je povezati svrhu deskriptivne i predmetne katalogizacije te klasifikacije s načinima pretraživanja u online knjižničnom katalogu. Također, isprobavajući različite kriterije pretraživanja u online katalogu studentima se često pokazuju i različiti rezultati pretraživanja čime in se uči kako upotreba različitih kriterija pretraživanja kataloga utječe na rezultate pretraživanja. Nakon ponavljanja gradiva s prethodne godine i vježbanja na praktičnim primjerima studenti pišu inicijalni test. Inicijalni test je uveden prije nekoliko godina s ciljem ponavljanja gradiva s prethodne godine, odnosno ponavljanja izrade pristupnica te kako bi se studenti pripremili za daljnje učenje katalogizacije. Akademske godine 2020./2021. nastava je izvedena online te su primjeri za katalogizaciju bili digitalizirani i postavljeni u mape na Moodle-u, sustavu za učenje na daljinu, a studenti su iste rješavali u virtualnoj učionici na ploči. Nastava uživo razlikovala se u tome što su studenti uživo primjere rješavali u paru i tako razmjenjivali znanja i iskustva, dok u online nastavi primjere rješavaju isključivo pojedinačno. Druga razlika je u tome što je edukator na prezentacije koje studenti kasnije koriste za učenje i ponavljanje tijekom pandemije postavio audio i video zapis svoga predavanja i pretraživanja online kataloga. Na taj način studenti su bili u mogućnosti ponovno poslušati nastavu ukoliko istoj nisu virtualno prisustvovali ili ukoliko žele ponoviti gradivo te isprobati sami pretraživanje u online katalogu. Ukoliko neki primjer studentima nije bio jasan, edukator bi tokom virtualne nastave podijelio svoj ekran na BigBlueButton-u i potražio novi primjer (sliku naslovne stranice) na Google images te potom isti u knjižničnom katalogu. Nakon inicijalnog ispita i ponavljanja pristupnica, do kraja semestra obrađene su sljedeće teme: 
- Kataložni opis, skupina 1. i 2.,

- Kataložni opis, skupina 4. i 5.,

- Kataložni opis, skupina 6. i 7.,

- Pomoćne kataložne jedinice,

- Višerazinski opis,

- Serijske publikacije i

- Sastavnice.

Za svaki od ovih tema studenti su u 4 sata praktičnih vježbi svakog tjedna, nakon ponavljanja gradiva prethodnih vježbi i prezentacije novog gradiva na nastavi, izrađivali bibliografski opis za otprilike desetak primjera. Uz primjere na nastavi studenti imaju i četiri domaće zadaće $u$ kojima rješavaju primjere na način prethodno naveden pod opisom kolegija Uvod u knjižničnu i informacijsku znanost. Za razliku od nastave uživo, studenti kod nedoumica oko primjera najčešće pitanja postavljaju pismeno u javnoj sobi za čavrljanje, a edukator odgovara preko mikrofona i kamere. Kod podučavanja kataložnog opisa edukator neprestano podsjeća studente na elemente opisa koje su učili na prvoj godini studija te na taj način ukazuje na to kako je postupak katalogizacije povezan sa svim poslovima koje će informacijski stručnjak obavljati na budućem poslu. U vezi s tim, prilikom učenja pomoćnih kataložnih jedinica studente se često pita da predvide korisnikovo ponašanje prilikom pretraživanja kataloga. $\mathrm{Na}$ taj način studenti razvijaju svijest o važnosti izrade općih uputnica i povezivanje s izvornim imenom autora, odnosno pristupnicom. Također, razvijaju svijest o okupljanu i kolokacijama kao najvažnijem cilju kataloga te o mogućem informacijskom ponašanju korisnika prilikom pretraživanja online knjižničnog kataloga.

Strojno čitljiva katalogizacija uči se nakon kolokvija iz »ručne« deskriptivne katalogizacije. Studenti koji savladaju kolokvij iz "ručne« katalogizacije u pravilu nemaju problema sa savladavanjem kolokvija iz strojno čitljive katalogizacije. Što se tiče podučavanja strojno čitljive katalogizacije na kolegiju Organizacija informacija I, studentima se najprije objasni što je i koji je cilj strojno čitljive katalogizacije (MARC) te koji sve formati postoje, a potom ih se upozna s ciljem i svrhom polja i potpolja formata UNIMARC u kojem rješavaju zadatke. Također, studentima se pokažu i primjeri različitih knjižničnih sustava i različitih formata koji se koriste u hrvatskim knjižnicama, primjerice knjižnični sustav Aleph (MARC21 format) u Nacionalnoj i sveučilišnoj knjižnici, knjižnični sustav CROLIST (UNIMARC format) u Gradskoj i sveučilišnoj knjižnici u Osijeku, knjižnični sustav Zaki (UNIMARC format) u Knjižnicama grada Zagreba i slično. Do 2019. godine studenti druge godine preddiplomskog studija radili su vježbe iz strojno čitljive katalogizacije isključivo u sustavu CROLIST (demo baza dostupna samo sa Filozofskog fakulteta). Demo verzija CROLIST-a za vježbanje studenata uključuje verziju u DOS$u$, no sam CROLIST ima također i Windows inačicu. S obzirom na važnost učenja i vježbanja katalogizacije u različitim knjižničnim sustavima, ostvarena je suradnja sa Institutom informacijskih znanosti IZUM iz Maribora te osiguravanje pristupa njihovom knjižničnom sustavu COBISS (format COMARC koji se temelji na UNIMARC formatu). Studenti druge godine preddiplomskog studija su tako u akademskoj godini 2019./2020. imali priliku krajem semestra odraditi 2 sata vježbi u sustavu COBISS te su njihove recenzije sustava i usporedba s CROLISTom dani u istraživačkom dijelu ovoga rada.

U dugogodišnjem radu edukator je zamijetio kako studenti često ne razumiju zašto se »ručna« katalogizacija vizualno razlikuje od bibliografskog zapisa iz online kataloga na ekranu računala 
(na primjer, prvi red kataložnog opisa je kod »ručnog" opisa uvučen ispod četvrtog slova pristupnice, dok u bibliografskom zapisu na ekranu to nije tako). Stoga je edukator »ručnu« katalogizaciju studentima predstavio vizualno kao popunjavanje "tri kvadrata« od kojih je prvi kvadrat za pristupnice, drugi kvadrat za kataložni opis i treći kvadrat za pomoćne kataložne jedinice. Nakon učenja izrađivanja zapisa u UNIMARC formatu na »ručnom « zapisu unutar svakog "kvadrata« studenti na papiru pišu polja i potpolja iz UNIMARCA (npr. 1. »kvadrat», pristupnica IVIĆ (700 a), IVO (700 b)). Nakon pokušaja podučavanja ovom vizualnom metodom, edukator je zamijetio napredak u studentskom shvaćanju »ručne« katalogizacije $i$ povezivanju s UNIMARC formatom.

Akademske godine 2020./2021. zbog pandemije uzrokovane koronavirusom, na kolegiju Teorija i praksa organizacije informacija koji se izvodi na diplomskom studiju, nastava je u potpunosti izvođena virtualno u knjižničnom sustavu COBISS. Razlozi korištenja samo i isključivo COBISS sustava prethodno su objašnjeni za kolegiji Organizacija informacija 1. Razlika u podučavanju studenata na diplomskoj razini je ta što većina studenata zaboravi katalogizirati jer između kolegija na drugoj godini preddiplomskog i drugoj godini diplomskog studija prođe gotovo dvije godine. Stoga je i na diplomskoj razini uveden inicijalni ispit prije kojega studenti ponavljaju na vježbama sve što su prethodno učili. Posebna pažnja se poklanja ponavljanju UNIMARC formata i rada u knjižničnom sustavu s obzirom da studenti druge godine diplomskog studija svih 100 sati praktičnih vježbi odrađuju u knjižničnom sustavu. Na vježbama studenti opisuju različite vrste knjižnične građe (elektronička građa, stara i rijetka građa i slično) te se bave pitanjima granularnosti u opisu na razini zbirke. Nedostatak je to što je Pravilnik Eve Verone primjenjiv samo na monografsku građu koja se uči na preddiplomskom studiju te se za ostalu građu, koja se uči katalogizirati na ovom kolegiju, moraju koristiti IFLAin i ISBD standardi. Također, ne postoje hrvatski udžbenici za katalogizaciju koje bi studenti mogli koristiti, a to je još jedan od razloga zašto je teško naučiti katalogizirati. Ono čime se studenti služe su interne upute za korištenje knjižničnim sustavom CROLIST koje je sastavio edukator, različite online upute za elektroničku građu koje su izašle u nakladi Nacionalne i sveučilišne knjižnice te interna online radna verzija sažetog UNIMARC formata za studente. Sve ove interne i formalne upute pomogle su studentima lakše savladati gradivo online tijekom pandemije. Također, sustav COBISS pokazao se iznimno dobrim tokom održavanja virtualne nastave s obzirom da su svi studenti istovremeno mogli biti online u sustavu i paralelno izrađivati zadatak s edukatorom koji je isti primjer izrađivao na svom ekranu koji je dijelio preko BigBlueButton-a. Što se tiče izrade zadataka na samim vježbama te kod kuće, edukator primjenjuje iste metode podučavanja kao kod kolegija na preddiplomskom studiju. Dakle, svi primjeri se prvo odrađuju "ručno" na virtualnoj ploči, potom "ručnom « opisu studenti dodijele polja i potpolja iz COMARC-a i naposljetku zajednički s edukatorom izrađuju zapis u sustavu COBISS. Razlika podučavanja katalogizacije na diplomskoj razini je u tome što su studenti do posljednje godine studija odslušali i kolegije koji se bave predmetnom katalogizacijom i klasifikacijom (Organizacija informacija 2 i Predmetno označivanje $i$ pretraživanje) te je pri samoj izradi zapisa u knjižničnom sustavu COBISS stavljen naglasak i na polja 675 (UDK) te na polje 610 (Slobodno oblikovane predmetne odrednice). Na ovaj način studenti pred sam završetak fakultetskog obrazovanja dobivaju cjelokupnu sliku katalogizacije te utjecaja koji kvalitetan bibliografski zapis ima na gotovo sve knjižničarske poslove. 


\section{Istraživanje}

\subsection{Metodologija i uzorak}

Glavni je cilj ovog istraživanja bio je prikupiti i analizirati podatke o stavovima i mišljenjima studenata Odsjeka za informacijske znanosti u Osijeku koji su strojno čitljivu katalogizaciju učili koristeći se knjižničnim sustavom COBISS. Sustav COBISS prvi je sustav u kojem su studenti imali priliku učiti i vježbati katalogizaciju uz dotadašnje korišteni sustav CROLIST. Pristup sustavu COBISS Odsjek za informacijske znanosti u Osijeku dobio je u dogovoru s Institutom informacijskih znanosti IZUM iz Maribora te su korisnička imena i šifre studenti dobili u veljači 2019. godine. Stoga je ovim istraživanjem također bilo važno saznati i stavove i mišljenja o usporedbi rada u ova dva knjižnična sustava, ali i iskustva i mišljenja o virtualnom izvođenju vježbi te online radu u COBISS sustavu od kuće.

Instrument koji se koristio bila je anketa uživo i online. Naime, s obzirom da su studenti druge godine preddiplomskog studija slušali kolegiji Organizacija informacija 1 prije početka pandemije, studente se na nastavi uživo zamolilo da nakon 2 sata vježbi i rada u sustavu COBISS napišu recenziju o sustavu te usporede svoja iskustva s radom u sustavu CROLIST. Studenti druge godine diplomskog studija su pak vježbe iz kolegija Teorija i praksa organizacije informacija u vrijeme pandemije odrađivali virtualno i isključivo u sustavu COBISS (sustav CROLIST ne podržava pristup online) te je zbog navedenog korištena online anketa. Online anketa je imala samo dva pitanja otvorenog tipa: 1) Molimo vas, napišite svoj kratki osvrt na rad u sustavu COBISS i 2). Jeste li zadovoljni načinom izvođenja vježbi virtualno u online knjižničnom sustavu COBISS? (Molimo obrazložite zašto.).

Uzorak ispitanika je namjeran, temeljen na odluci istraživača s obzirom da je riječ o uzorku izabranom na temelju iskustva rada u knjižničnom sustavu koji se istražuje. U popunjavanju ankete sudjelovalo je 10 ispitanika s druge godine preddiplomskog studija te 12 ispitanika $\mathrm{s}$ druge godine diplomskog studija Odsjeka za informacijske znanosti u Osijeku. Nakon što su svi osvrti i odgovori prikupljeni u studenom 2020. godine, obrađeni su metodom sadržajne analize pri čemu su imena svih ispitanika koji su sudjelovali bila kodirana te je tako osigurana anonimnost studenata. Studenti druge godine preddiplomskog studija označeni su simbolima SP1- SP10, a studenti druge godine diplomskog studija simbolima SD1-SD12.

\subsection{Rezultati}

Najviše studenata je navelo jednostavno korištenje kao glavnu prednost sustava COBISS. Ispitanici su opisali iskustvo korištenja sustava kao jednostavno (SP1-SP4, SP8, SP9, SD1, SD2, SD4, SD6, SD7-SD12), pregledno (SP4, SP8, SD4, SD6, SD8, SD10, SD11) i lagano (SP2, SP4, SP5, SP7, SP9, SP10, SD8, SD12). Nadalje, kao sljedeću prednost navode ukazivanje sustava na pogreške prije samog pohranjivanja zapisa (SP1, SP2, SP5, SP8-SP10, SD1, SD3). Primarno naglašavaju kako je to iznimno korisno za katalogizaciju (SP1, SP2, SD4, SD5, SD10) upravo zbog toga što omogućava prepoznavanje pogreške prije završetka izrade zapisa (SP5, SP9, SP10), što ukazuje na intuitivnost samoga sustava (SD3). Pri tome se ispitanici referiraju na objašnjenja grešaka i povratnu informaciju koje sustav prikazuje ukoliko je prepoznata greška, a na taj način COBISS usmjerava korisnike na ono što trebaju ispraviti ili popraviti (SP8). Samim time katalogizacija je znatno lakša (SP1, SD4) te brža (SP3, SP4, SP5). Osim toga, samo učenje katalogizacije iz perspektive studenata je također puno jednostavnije i brže (SP3) u COBISS-u, 
te je lakše pristupiti identifikacijskom broju zapisa (SP10) koji je važan pri kasnijem traženju kataložnog zapisa i provjeri istoga.

Također, studenti preferiraju način na koji COBISS prikazuje polja i potpolja za unos podataka (SP2, SP3, SP5, SP6, SP9, SD1, SD5, SD7, SD8, SD10) s obzirom na to da se u CROLIST-u kodovi polja manualno moraju upisivati (SP3, SP9). Točnije, u COBISS-u se popis svih polja nalazi sa lijeve strane te tako korisnici samo trebaju popunjavati tražene podatke, odnosno ne moraju sami unositi polje koje slijedi niti znati koje je to polje (SP5, SD1, SD6). Sukladno s tim, lakše je snalaženje u sustavu (SP6, SD5), a od korisnika se ne zahtijeva pretjerano razmišljanje prilikom kreiranja zapisa (SP2).

Većina studenata osvrnula se i na izgled sučelja COBISS kao karakteristike koja utječe na uspješnost rada u sustavu. Moderno sučelje, odnosno suvremeni dizajn (SP1, SP5, SP9) uz jednostavnost, praktičnost i preglednost (SP6, SP7, SD3, SD4, SD5, SD6) čine sustav lakšim za korištenje te privlačnijim studentima za rad (SP7). Cjelokupna preglednost sustava kao karakteristika koja se odnosi na više faktora poprilično utječe na dojam kojeg su studenti stekli radom u COBISS-u (SP1, SP6, SP8, SD4, SD6, SD8, SD10, SD11).

Nadalje, SP2 navodi kako je lakše pretraživanje zapisa rezultat brojnih prednosti koje sustav ima. SP3 komentira kako je program odličan, dok SP7 i SD3 opisuju pozitivno iskustvo tijekom korištenja budući da je sustav bez kompliciranih naredbi, vrlo jasan i razumljiv. Osim toga, SD4 također navodi kako je zadovoljan sa sustavom jer je olakšao i razumijevanje katalogizacije, a prikaz i snalaženje unutar sustava su mnogo bolji nasuprot CROLIST-a. Provjeru valjanosti zapisa SP8 naglašava kao najveću prednost, a SP10, SD9 i SD12 s obzirom na ukupan dojam opisuju COBISS kao zanimljiv program. $S$ druge strane, šestero studenata osvrnulo se i na sustav CROLIST u kontekstu stvaranja bolje usporedbe rada u sustavima. Tako SP1 opisuje CROLIST kao zastarjelog i kompliciranijeg za korištenje, a nemogućnost pregleda svih polja istovremeno te ručno unošenje istih uz neprestano vraćanje na početak SP2 i SP3 navode kao glavne nedostatke. Također, SP7 navodi kako je CROLIST složeniji sustav, puno kompleksniji za korištenje, što otežava vježbanje i učenje katalogizacije, dok SP10 dodaje samostalno traženje pogrešaka kao komplikaciju kod sustava CROLIST.

S druge strane, SD4 komentira kako se nije znala snaći unutar sustava COBISS unatoč uputama profesorice. Jedan od studenata (SD12) predlaže kako bi bilo bolje kada bi COBISS bio dostupan i na hrvatskome jeziku zbog toga što slovenski jezik, iako je sličan hrvatskome, nije dovoljno razumljiv studentima. Uzimajući u obzir navedene osvrte studenata, jasno je vidljivo da studenti COBISS smatraju boljim i praktičnijim sustavom, posebice zbog modernog sučelja, lakše organizacije, preglednosti i opće upotrebe. Studenti vidljivo pozitivnije reagiraju na rad u takvome sustavu te su rezultati razumijevanja i učenja znatno bolji.

S obzirom na postojeću situaciju uzrokovanu pandemijom koronavirusa, studente druge godine diplomskog studija pitalo se jesu li zadovoljni provođenjem praktičnih vježbi virtualno putem BigBlueButton-a. Sukladno s tim, većina je studenata zadovoljna izvođenjem vježbi online (SD1, SD2, SD6, SD8, SD9, SD10, SD11). Studenti su kao pozitivne aspekte virtualnog okruženja naveli odlične i dobro organizirane vježbe (SD2, SD3, SD5, SD7, SD10, SD11). Unatoč tome, šest od dvanaest studenata naglasilo je i susretanje s tehničkim poteškoćama tijekom virtualne nastave, što je zatim otežalo njezino praćenje. Navedeni razlozi su prvenstveno spor Internet (SD1, SD2, SD4, SD8, SD12), zatim problemi s računalima (SD1, SD8, SD12), usporen 
rad zbog uključivanja u razgovor putem mikrofona ili u sobi za čavrljanje (SD2, SD8), te teže praćenje zbog paralelnog praćenja nastave i rada u programu (SD2, SD5, SD12). Usto, vezani su i negativni aspekti virtualnog provođenja vježbi, poput nezgodnog praćenja i unošenja u sustav (SD3, SD7, SD10, SD11), neprijavljivanje poteškoća i nerazumijevanje uputa (SD11), zatim navođenje kako bi provođenje vježbi bilo bolje uživo (SD4, SD10, SD12) zbog preglednosti ili lakšeg uočavanja pogrešaka na studentskim ekranima uživo. Međutim, SD2 komentira kako nitko nije zakinut za pomoć, dok SD7 navodi kako nema zamjerki jer je profesorica susretljiva, a materijali dostupni online.

\section{Rasprava i zaključak}

Učenje strojno čitljive katalogizacije nastavak je učenja "ručne» deskriptivne katalogizacije gotovo u svakom kolegiju na kojem se ista podučava. Edukator treba studentima biti u mogućnosti povezati gradivo deskriptivne katalogizacije te primjenu pravila i standarda $\mathrm{s}$ gradivom strojno čitljive katalogizacije, odnosno rada u MARC formatima. Također, zadatak edukatora je studentima pokazati kako knjižnični sustav za katalogizaciju funkcionira te in osposobiti za snalaženje i rad u istome. Istraživanje je pokazalo kako su studenti iznimno zadovoljni radom u sustavu COBISS te kao glavne prednosti ističu njegovu jednostavnost korištenja, lakoću snalaženja i pretraživanja u sustavu te praktičnost, posebice zbog modernog sučelja, njegove organizacije, preglednosti i opće upotrebe. Većina studenata posebno se osvrnula na intuitivnost sustava, odnosno ukazivanje sustava na moguće greške prije samog pohranjivanja zapisa. Pri tome se ispitanici referiraju na objašnjenja grešaka i povratne informacije koje sustav prikazuje kao obavijest ukoliko je prepoznata greška u bibliografskom zapisu. Na taj način COBISS usmjerava korisnike na ono što trebaju ispraviti ili popraviti prije pohranjivanja zapisa. $U$ vezi sa ovim, šestero studenata navodi kako im je ova značajka sustava olakšala sam postupak katalogizacije te da je sâmo učenje katalogizacije iz perspektive studenata puno jednostavnije i brže. Također, deset studenata navodi prikaz polja i potpolja za unos podataka u sustavu COBISS kao najvažniju značajku u odnosu na sustav CROLIST u kojem se svako polje UNIMARC-a mora upisivati manualno. Što se tiče nedostataka sustava COBISS, jedini nedostatak koji je naveo jedan student je nepostojanje verzije sustava na hrvatskom jeziku s obzirom na činjenicu da svi ne razumiju slovenski jezik.

Važna perspektiva ovoga rada je perspektiva edukatora o podučavanju katalogizacije uživo i u virtualnom okruženju. Opis praktičnih vježbi iz kolegija na kojima se podučava katalogizacija te metode koje edukator primjenjuje, primjerice neprestano davanje primjera iz stvarnog života te ravnoteža teorije i prakse u smislu učenja primjene teorije na praktičnim primjerima, poklapaju se s rezultatima istraživanja autora Snowa i Hoffmana (2015). Također, tu je još jedan element koji čini razliku i utječe na studentsko učenje katalogizacije, a poklapa se $s$ navedenom studijom. Taj element je upotreba i primjena katalogizacije u kontekstu stvarnih situacija, primjerice stavljanje katalogizacije u kontekst rada u knjižnici, ukazivanje na činjenicu kako kvalitetna katalogizacija može pomoći korisniku pri pretraživanju kataloga, pokazivanje primjera u lokalnom online katalogu i slično. Opis sata vježbi katalogizacije iz perspektive edukatora pokazao je i poklapanja s načinima podučavanja i iznalaženja najboljih načina prijenosa znanja i vještina s brojnim drugim autorima koji su se bavili istom temom poput Intnera (2002), Hoermana (2002), Miksa (2008) i drugih. Što se tiče samog podučavanja u virtualnom okruženju, edukator smatra kako se kvaliteta vježbi čak i poboljšala s obzirom na to da je uz pomoć BigBlueButton sustava i sustava COBISS bilo moguće istovremeno dijeliti 
studentima na ekranu više prozora te je time bilo olakšalo navigiranje, prezentiranje tijekom izvođenja vježbi te korištenje i predstavljanje knjižničnog sustava studentima. Što se tiče studentske perspektive virtualnih vježbi, studenti su većinom zadovoljni iako kao nedostatke navode uglavnom tehničke poteškoće poput spore internetske veze, problema s računalom i otežano praćenje zbog paralelnog praćenja nastave i rada u knjižničnom sustavu. Kao najveće prednosti studenti navode dobro organizirane vježbe, susretljivost edukatora te online dostupnost svih materijala s nastave.

Zaključno, možemo reći kako je katalogizacija jedan od najizazovnijih predmeta za podučavanje, pri čemu edukator mora biti svjestan da svaki student ima različite načine, odnosno stil učenja i razmišljanja. Također, edukator treba biti i poprilično pažljiv i selektivan pri odabiru sadržaja i praktičnih zadataka jer postoji ograničenje koliko gradiva student može usvojiti tijekom vremenskog razdoblja izvođenja vježbi. Tempo i vrijeme te vrsta izvođenja (uživo ili online) kolegija na kojem se uči katalogizacija moraju se dobro razmotriti, a treba predavati na način koji omogućava studentima graditi vještine katalogiziranja i priprema ih za buduće poslove. No, najvažniji cilj svakog edukatora je davanje "cjelovite slike«, odnosno svrhe i korisnosti katalogizacije. To znači da je potrebno naučiti studente ne samo kako katalogizirati, već i zašto katalogizirati.

\section{Reference}

Al Hijji, K. Z. i Fadlallah, O. S., 2013. Theory versus practice in cataloging education in Oman: students' perspectives. Cataloging \& Classification Quarterly, 51(8), 929-944.

American Library Association (ALA), 2009. ALA's core competences of librarianship. Dostupno na:

http://www.ala.org/educationcareers/sites/ala.org.educationcareers/files/content/careers/ corecomp/corecompetences/finalcorecompstat09.pdf [8.11. 2020].

American Library Association (ALA), 1999. Congress on professional education: focus on education for the first professional degree. Dostupno na:

https://www.ala.org/ala/hrdr/educprofdev/congressprofessional.htm [8. 11. 2020].

ALCTS Board, 2017. Core competencies for cataloging and metadata professional librarians. Dostupno na: https://alair.ala.org/handle/11213/7853 [8. 11. 2020].

Calhoun, K., 2006. The changing nature of the catalog and its integration with other discovery tools: final report. Dostupno na: https://www.loc.gov/catdir/calhoun-reportfinal.pdf [5. 11. 2020].

Chaudhry, A. S. i Komathi, N. C., 2002. Requirements for cataloguing positions in the electronic environment. Technical Services Quarterly, 19(1), 1-23.

Coetzee, H. S. i de Boer, A., 2000. The thinking preferences of learners in cataloguing and classification. Dostupno na: https://archive.ifla.org/IV/ifla66/papers/014-171e.htm [3. 11. 2020].

Crowley, B., 2007. Don't let Google and the pennypinchers get you down: defending (or redefining) libraries and librarianship in the age of technology. Dostupno na:

http://eprints.rclis.org/9373/1/Crowley 2007.pdf [3. 11. 2020]. 
Damasco, T. i McGurr, M. J., 2008. A survey of cataloger perspectives on practicum experiences. Cataloging \& Classification Quarterly, 45(4), 43-64.

Elrod, J. M., 2008. The case for cataloguing education. The Serials Librarian, 55(1-2), 1-10.

Glasser, S., 2007. The changing face of cataloging positions at academic institutions. The Serials Librarian, 51(3-4), 39-49.

Gorman, M., 2002. Why teach cataloguing and classification? Cataloging \& Classification Quarterly, 34(1-2), 1-13.

Graf, S., Viola, S. R., Leo, T. i Kinshuk, 2007. In-depth analysis of the Felder-Silverman Learning Style Dimensions. Journal of Research on Technology in Education, 40(1), 79-93.

Hall-Ellis, S. D., 2005. Descriptive impressions of entry-level cataloger positions as reflected in American Libraries, AutoCAT, and the Colorado State Library Jobline, 2000-2003. Cataloging \& Classification Quarterly, 40(2), 33-72.

Hill, J. S., ur., 2013. Education for cataloging and the organization of information: pitfalls and the pendulum. New York: Routledge.

Holley, R. P., 2002. Cataloging: an exciting subject for exciting times. Cataloging \& Classification Quarterly, 34(1/2), 43-52.

Hsieh-Yee, I., 2008. Educating cataloging professionals in a changing information environment. Journal of Education for Library and Information Science, 49(2), 93-106.

Indiana University, Task Group on the Future of Cataloging, 2006. A White Paper on the Future of Cataloging at Indiana University. Dostupno na:

http://citeseerx.ist.psu.edu/viewdoc/download?doi=10.1.1.183.3760\&rep=rep1\&type=pdf

[5. 11. 2020].

Intner, S. S., 2002. Persistent issues in cataloging education: considering the past and looking toward the future. Cataloging \& Classification Quarterly, 34(1-2), 15-28.

Joudrey, D. N., 2008. Another look at graduate education for cataloging and the organization of information. Cataloging \& Classification Quarterly, 46(2), 137-181.

Leonard, B. i Pontau, D., 1991. Sculpting future librarians through structured practicums: the role of academic librarians. Journal of Academic Librarianship, 17(1), 26-30.

Letarte, K. M., Turvey, M. R., Borneman, D. i Adams, D. L., 2001. Practitioner perspectives on cataloging education for entry-level academic librarians. Library Resources and Technical Services, 46, 11-22.

MacLeod, J. i Callahan, D., 1995. Educators and practitioners reply: an assessment of cataloging education. Library Resources \& Technical Services, 39(2), 153-165.

Marcum, D. B., 2006. The future of cataloging. Library Resources \& Technical Services, 50(1), $5-9$.

Mering, M., 1998. Future of professional catalogers: a report of the ALCTS creative ideas in technical services discussion group meeting. Technical Services Report, 15(3), 84-85. 
Miksa, S. D., 2008. Educators: what are the cataloging issues students get excited about?: professional and intellectual appeals of cataloging and students' misconceptions of cataloging. Cataloging \& Classification Quarterly, 45(3), 17-24.

Morris, D. E. i Wool, G., 1999. Cataloging: librarianship's best bargain. Library Journal, 124(11), 44-46.

Normore, L. F., 2012. "Here be Dragons «: a wayfinding approach to teaching cataloguing. Cataloging \& Classification Quarterly, 50(2-3), 172-188.

Odsjek za informacijske znanosti, 2020a. Povijest. Dostupno na: https://www.ffos.unios.hr/infoznanosti/povijest [8. 11. 2020].

Odsjek za informacijske znanosti, 2020b. Studijski programi. Dostupno na: https://www.ffos.unios.hr/infoznanosti/studijski-programi [8. 11. 2020].

Petr, K., 2008. Education for cataloguing and classification at the Department of Information Sciences in Osijek, Croatia. Cataloging \& Classification Quarterly, 45(4), 25-42.

Rinehart, A., Sharkey, J. i Kahl, C., 2015. Learning style dimensions and professional characteristics of academic librarians. College \& Research Libraries, 76(4), 450-468.

Saye, J., 2002. Where are we and how did we get here? or, the changing place of cataloging in the library and information science curriculum: causes and consequences. Cataloging \& Classification Quarterly, 34(1/2), 121-143.

Snow, K. i Hoffman, G. L., 2015. What makes an effective cataloging course? A study of the factors that promote learning. Library Resources and Technical Services, 59(4), 187-199.

Spillane, J., 1999. Comparison of required introductory cataloging courses, 1986 to 1998 Library Resources and Technical Services, 43(4), 223-30.

Špiranec, S. i Ivanjko, T., 2012. Predmetni jezici s korisničkim jamstvom: što možemo naučiti od folksonomija? U: Hassenay, D. i Krtalić, M., ur. Seminar Arhivi, knjižnice, muzeji: mogućnosti suradnje u okruženju globalne informacijske infrastrukture: zbornik radova. Zagreb: Hrvatsko knjižničarsko društvo. Str. 57-73.

Turvey, M. R. i Letarte, K., 2002. Cataloging or knowledge management: perspectives of library educators on cataloging education for entry-level academic librarians. Cataloging \& Classification Quarterly, 34(1/2), 165-187. 